\title{
Current Stem Cell Biomarkers and Their Functional Mechanisms in Prostate Cancer
}

\author{
Kaile Zhang ${ }^{1,2,+}$, Shukui Zhou ${ }^{1,+}$, Leilei Wang ${ }^{3}$, Jianlong Wang ${ }^{4}$, Qingsong Zou ${ }^{1}$, \\ Weixin Zhao ${ }^{2}$, Qiang Fu ${ }^{1, *}$ and Xiaolan Fang ${ }^{5, *}, \ddagger$ \\ 1 The Department of Urology, Affiliated Sixth People's Hospital, Shanghai JiaoTong University, \\ Shanghai 200233, China; great_z0313@126.com (K.Z.); 2005507098@163.com (S.Z.); \\ zou_qingsong@126.com (Q.Z.) \\ 2 Wake Forest Institute for Regenerative Medicine, Winston-Salem, NC 27101, USA; wezhao@wakehealth.edu \\ 3 VIP Department of Beijing Hospital, Beijing 100730,China; luckyleileiaaa@sina.com \\ 4 Urology Department of Beijing Hospital, Beijing 100730, China; wjlspplaaa@sina.com \\ 5 Department of Cancer Biology, Wake Forest University School of Medicine, Wake Forest Institute for \\ Regenerative Medicine, Winston-Salem, NC 27101, USA \\ * Correspondence: jamesqfu@aliyun.com (Q.F.); afang@nygenome.org (X.F.); \\ Tel.: +86-21-2405-8372 (Q.F.); +1-434-409-8076 (X.F.) \\ $+\quad$ These authors contributed equally to this work. \\ $\ddagger$ Current address: New York Genome Center, 101 Avenue of the Americas, New York, NY 10013, USA. \\ Academic Editor: Carsten Stephan \\ Received: 30 May 2016; Accepted: 9 July 2016; Published: 19 July 2016
}

\begin{abstract}
Currently there is little effective treatment available for castration resistant prostate cancer, which is responsible for the majority of prostate cancer related deaths. Emerging evidence suggested that cancer stem cells might play an important role in resistance to traditional cancer therapies, and the studies of cancer stem cells (including specific isolation and targeting on those cells) might benefit the discovery of novel treatment of prostate cancer, especially castration resistant disease. In this review, we summarized major biomarkers for prostate cancer stem cells, as well as their functional mechanisms and potential application in clinical diagnosis and treatment of patients.
\end{abstract}

Keywords: prostate cancer; cancer stem cell; stem cell biomarker

\section{Introduction}

Prostate cancer (PCa) is the most common non-skin cancer in American men [1,2]. Standard PCa treatment includes radical prostatectomy, radiotherapy, chemotherapy and castration (either by drug or by surgery, mainly for androgen sensitive $\mathrm{PCa}$ ), as well as immunotherapy and palliative therapy (mainly for castration resistant PCa (CRPC)). CRPC is responsible for majority of the PCa-related deaths [3], and currently there are two major hypotheses of CRPC carcinogenesis, the adaptive mechanism and the selective mechanism [4]. The adaptive mechanism suggests gene mutations in PCa cells (e.g., mutations of androgen receptor (AR)), dysregulated expression of genes, etc., contribute to CRPC development [5]. The selective mechanism, which is emerged in the last few decades, suggests that pre-existing castration-resistant subclones in primary PCa tissues and cancer stem cell selection dominates CRPC development (Figure 1) [6-8]. Recently, it has been suggested that stem-cell directed differentiation therapy could promote differentiation of cancer stem cells and sensitize them to anticancer drugs (such as synergistic androgen signaling blocking agents) [9]. 


\section{\begin{tabular}{|l|l|l}
\hline PROSTATE CANCER Adapted from KEGG database & \\
\hline
\end{tabular}}

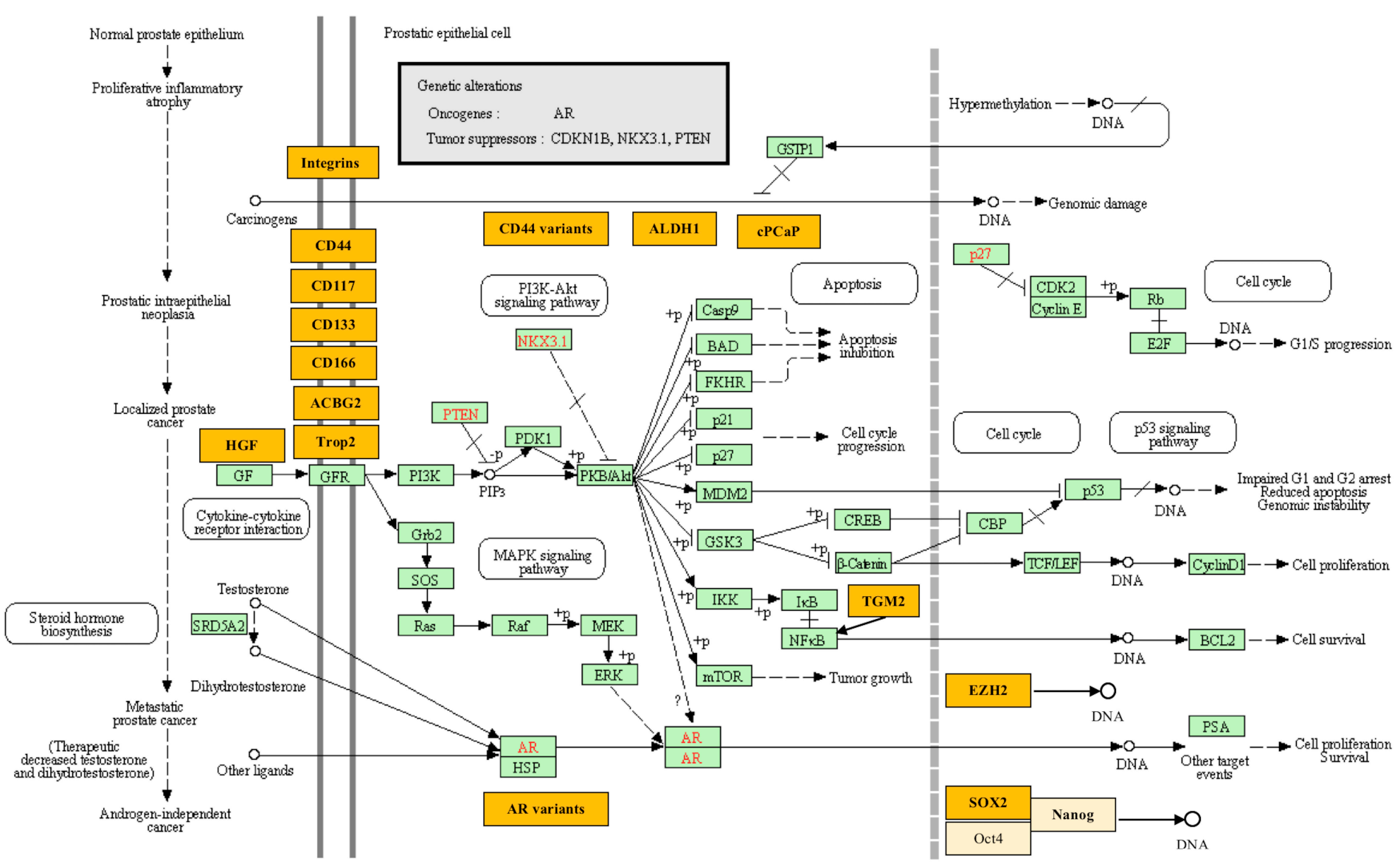

05215126616
(c) Kane hisa Iaboratories

Figure 1. The mechanism and pathway map of the prostate cancer (modified based on KEGG database). Solid line between genes/molecules indicates direct regulation, while dashed lines indicates possible indirect regulation. Circle indicates a group of similar molecules (instead of a specific one). Biomarkers discussed in this review are highlighted in orange and in bold font, related molecules that are newly discovered are in yellow. Classic biomarkers included in KEGG prostate cancer pathway are highlighted in green. Key regulators in classical pathways involved in PCa are displayed in red (e.g., NKX3.1, PTEN, AR). 
Cancer stem cells (CSCs) were defined as cells with capacity of self-renewal and proliferation in cancer tissue [8]. Over years, scientists have been arguing about the origin of cancer stem cells. CSCs were suggested to originate from mutated normal stem cells, from mutated progenitor cells in the process of differentiation which re-gains the characteristics of stem cells, or from mature cells that re-acquired self-renewal ability [10]. Various cell surface markers were used to isolate CSCs, whose proliferative potential was verified by in vitro andin vivo assays (Tables 1 and 2). This review summarizes recent research progress of current stem cell markers in PCa.

Table 1. Summary of prostate cancer stem cell biomarkers based on location and function.

\begin{tabular}{ccccccc}
\hline Biomarker & $\begin{array}{c}\text { Transmembrane } \\
\text { Protein }\end{array}$ & Glycoprotein & Enzyme & $\begin{array}{c}\text { Transcription } \\
\text { Factor }\end{array}$ & $\begin{array}{c}\text { Extracellular } \\
\text { Protein }\end{array}$ & mRNA \\
\hline Integrins & Yes & - & - & - & - & - \\
CD44 & Yes & - & - & - & - & - \\
CD133 & Yes & Yes & - & - & - & - \\
CD166 & Yes & - & - & - & - & - \\
Trop2 & Yes & Yes & - & - & - & - \\
CD117 & Yes & - & Yes & - & - & - \\
ALDH1 & - & - & - & Yes & - & - \\
ABCG2 & Yes & - & - & - & - & - \\
SOX2 & - & - & - & Yes & - & - \\
EZH2 & - & - & Yes & - & - & - \\
cPAcP & - & - & Yes & - & - & Yes \\
AR splice & - & - & - & - & - & - \\
variants & - & - & - & - & Yes & - \\
HGF & - & - & Yes & - & - & - \\
TGM2 & - & & - & - & - & - \\
\hline
\end{tabular}

Trop2, tumor-associated calcium signal transducer 2; ALDH1, aldehyde dehydrogenase 1; ABCG2, ATP binding membrane transporters; cPAcP, cellular prostatic acid phosphatase; HGF, hepatocyte growth factor; TGM2, transglutaminase II; SOX2, SRY-box 2; EZH2, enhancer of zeste 2 polycomb repressive complex 2 subunit.

Table 2. Summary of verifying studies and possible pathways of prostate cancer stem cell biomarkers.

\begin{tabular}{|c|c|c|c|c|}
\hline Markers & PCa Cell Lines & Primary PCa Tissues & Mouse Models & $\begin{array}{l}\text { Possible Involved } \\
\text { Pathway in PCa }\end{array}$ \\
\hline Integrins & Yes & Yes & - & - \\
\hline CD44 & Yes & Yes & - & - \\
\hline CD133 & Yes & Yes & - & - \\
\hline CD166 & - & - & Yes & - \\
\hline Trop2 & - & - & Yes & - \\
\hline CD117 & - & - & Yes & - \\
\hline ALDH1 & Yes & - & - & - \\
\hline ABCG2 & Yes & Yes & - & - \\
\hline SOX2 & - & Yes & - & - \\
\hline $\mathrm{EZH} 2$ & - & Yes & - & - \\
\hline $\mathrm{cPAcP}$ & Yes & - & - & - \\
\hline AR splice variants & Yes & - & - & $\mathrm{AR}$ \\
\hline HGF & Yes & - & - & AR \\
\hline TGM2 & Yes & - & - & NF- $k B$ \\
\hline
\end{tabular}

PCa, Prostate cancer.

\section{Integrins}

Integrins are a family of transmembrane receptors known to participate in cell-cell adhesion and cell-surface mediated signaling, serving as bridges for cell-cell and cell-extracellular matrix (ECM) interactions [11]. Integrin could interact with specific ligands to transfer signals through cell-cell or cell-ECM interactions and stimulate expression of downstream target genes. Integrins were generally 
overexpressed in PCa [12,13]. In PCa, expression of $\alpha 2$-integrin and EZH2 is observed in a small fraction of cancer cells, which is supportive for their role as stem cell marker [14]. $\alpha 2 \beta 1$ integrin plays an important role in epithelia-stroma interaction, which is suggested to contribute to selective bone metastasis [12]. In the meantime, it could be a new marker to screen for prostate stem cells. Collins et al. [15] has discovered that the prostate stem cells expressing $\alpha 2 \beta 1$ integrin locate at basal epithelial layer. Approximately $1 \%$ of basal cells examined by confocal microscopy were integrin positive, and these cells could be isolated directly from the tissue on the basis of rapid adhesion to type I collagen. This isolated cell population displays basal cell phenotype, marked by expression of CK5 and CK14 and lack of expression of differentiation-specific markers (such as prostate specific antigen (PSA) and prostatic acid phosphatase (PAP)). These prostate stem cells could be cultivated in vitro and display much greater capability to form colonies in vitro (comparing to total basal cell population). When $\alpha 2 \beta 1$ overexpressing cells and stromal cells were transplanted subcutaneously into nude mouse, they could form structure of normal prostate gland prostate-specific differentiation [15].

Microarray experiments performed by several independent groups found that Integrin- $\alpha 6$ (also known as CD49f) is consistently overexpressed in hematopoietic, neural, and embryonic stem cells, and it is suggested as an effective cell stemness marker [16]. It has been used for characterization of prostatic progenitor cells [17,18], and was suggested as an emerging biomarker for PCa evaluation $[14,19,20]$.

\section{CD44}

CD44 is a single-pass type I transmembrane protein and an important cellular adhesion molecule related to signaling to extracellular matrix. CD44 was considered as a marker of cancer stem cells from many organs including prostate [21-23]. It was located extensively on cell membrane and is important for cell adhesion and signal transduction. It was reported that CD44 positive cells from primary prostatic tumor tissues possess cell stemness [24]. Molecular studies demonstrated that CD44 PCa cells retain certain intrinsic properties of progenitor cells [25]. CD44 ${ }^{+}$cells express high levels of stemness genes including Oct-3/4, Bmi, $\beta$-catenin and Smoothened (SMO) $[2,26,27]$. Kasper et al. discovered that in PCa cells (such as LNCaP, DU145 and PC3), CD44 positive cells had much greater proliferative capability than CD44 negative cells [28]. Van et al. isolated the DU145 cells from CD44 ${ }^{+}$ and CD44- Cells and tested the gene expression of stem cells by RT-PCR. Low expression of luminal cell markers (e.g., CK18) and AR were observed in CD44 ${ }^{+}$cells, whereas the genes highly related to stem cell proliferation and differentiation were overexpressed [29]. Recently, CD44 expression level was reported to be correlated with PCa grade in prostate biopsy samples [30], and proteomics analysis showed that $\mathrm{CD} 44^{+}$cells had positive correlation with genes related to cancer proliferation and metastasis [31]. However, Ugolkov discovered that expression of CD44 and Oct4 were observed in large populations of benign and malignant cells in the prostate, which is somewhat contradictory to the definition of stem cells as a small fraction of the total cell population [32]. Their results suggested that combined expression of embryonic stem cell markers EZH2 and SOX2 might be used to identify potential cancer stem cells as a minor $(<10 \%)$ subgroup in $\mathrm{CD}_{4} 4^{+}$prostatic adenocarcinoma cells [32].

Recently, quite a few thorough analyses have been done on CD44 isoforms that are generated through alternative splicing of CD44 precursor mRNA. Those CD44 variants function distinctly in $\mathrm{PCa}$ and might serve as independent markers comparing to total CD44 expression level. For example, $\mathrm{CD} 44 \mathrm{v} 2$ correlated with a better recurrence-free survival rate in PCa patients and is underexpressed in metastatic PCa cell lines [33]. Another well-studied isoform is CD44v6, which is associated with PCa proliferation, invasion, adhesion, metastasis, chemo-/radioresistance, and the induction of epithelial-mesenchymal transition (EMT) as well as the activation PI3K/Akt/mTOR and Wnt signaling pathways, and CD44v6 expression was closely associated with conventional prognostic factors and is identified as significant predictor for biochemical recurrence in PCa $[34,35]$. CD44v7-10 were overexpressed in $\mathrm{PCa}$, and knock-down of CD44v7-10 by RNAi would significantly decrease invasion and migration in PCa cells [36]. 
Taken together, those results demonstrated CD44 RNA isoforms, but not total CD44 protein, might serve as specific marker for prostate cancer stem cells, though total CD44 protein level might still serve as a stem cell marker for other types of cancers [29].

\section{CD133}

CD133 is a glycoprotein with five transmembrane domains, generally expressed in various stem cells and endothelial progenitor cells but not in mature endothelial cells [37]. CD133 has been widely used, usually in combination with other stem cell markers such as CD44 and $\alpha 2 \beta 1$ integrin, to isolate cancer stem cells from prostate tumors with different Gleason grade, including cells from both primary and metastatic lesions [38-41]. Approximately $0.1 \%$ of cells in any prostate tumor displayed this phenotype, though there was no correlation between the number of $\mathrm{CD} 44^{+} / \alpha 2 \beta 1 \mathrm{hi} / \mathrm{CD} 133^{+}$cells and tumor grade [23]. In normal prostate tissues, CD133 expression was observed in both basal and luminal cells [42]. Although its expression in normal prostate tissue is pretty low, CD133 is usually overexpressed in inflammation cell population [43].

Prostatic basal cells could be enriched based on $\alpha 2 \beta 1$ integrin (hi) expression and further enriched for stem cells using CD133 in non-tumorigenic BPH-1 cells [44]. It is demonstrated that the tumorigenic potential did not reside in the $\mathrm{CD} 133^{+}$stem cells but was consistently observed in the CD133population [45]. These data confirmed that benign basal cells include cells of origin of prostate cancer and suggested that proliferative $\mathrm{CD} 133^{-}$basal cells are more susceptible to tumorigenesis compared to the $\mathrm{CD} 133^{+}$-enriched stem cells. These findings challenged the current dogma that normal stem cells and cells of origin of cancer are the same cell type(s) [45]. Intensive studies need to be done to learn more about the role of CD133 in PCa origination.

\section{ALDH1}

ALDH1 was suggested as a stem cell marker for both normal and tumor tissues [46]. As a cytoplasmic enzyme, ALDH1 has multiple intracellular aldehydes which can be converted into carboxylic acids, and could be involved in intracellular degradation of cell toxic substances [47]. ALDH1 expression was reported to be correlated with tumor grade and prognosis in PCa patients [48]. Burger et al. [49] found that cells with high ALDH enzymatic activity have greater in vitro proliferative potential than cells with low ALDH activity. Similar results were observed in an in vivo prostate reconstitution assay [49]. Thus, ALDH enzymatic activity might be used as a functional marker of prostate stem/progenitor cells and allow for simple, efficient isolation of cells with primitive features. ALDH $\alpha 2+/ \alpha 6+/ \alpha \mathrm{V}+\mathrm{CD} 44^{+}$cells also displayed high colonization in vitro and highly invasive tumorigenesis and aggressive metastasis characteristics in vivo [50]. p63 cytoplasmic aberrance is associated with high ALDH1A1 expression, and it was found that cytoplasmic p63 levels were significantly associated with the frequency of proliferating cells and cells undergoing apoptosis in prostate cancers [51]. These components are suggested to have an important role in prostate cancer progression and may be used as a panel of molecular markers [52].

The aldehyde dehydrogenase enzymes are likely to protect stem cells by detoxification of cell toxic compounds, which indicates that ALDH1 might prevent prostate cancer stem cells from conventional chemotherapy attack, while effective inhibition of ALDH1 could enhance the chemotherapy efficiency. Thus, ALDH1 could not only be used as a prostate cancer stem cell marker for prognosis, but also as a potential drug target in cancer treatment.

\section{ATP Binding Membrane Transporters (ABCG2, Also Known as Breast Cancer Resistant Protein or BCRP)}

Studies have shown that prostate cancer contains side population cells (SP cells), which could be isolated by flow cytometry techniques based on behavioral characteristics of stem cells. SP cells have stem cell properties that are exclusively mediated by ABCG2. As a result, ABCG2 is considered as a marker of SP cells, as well as a cancer stem cell marker. 
ABCG2 is ATP binding membrane transporters, and is related to prostate cancer multi-drug resistance [10]. After castration, ABCG2+/AR- prostate cancer stem cells could be isolated from prostate cancer tissues, and it is suggested that ABCG2 expression might protect prostate cancer stem cells from castration, chemotherapy and hypoxic environment. ABCG2 has been suggested as a biomarker for treatments targeting on prostate cancer stem cells [53]. Interestingly, Patrswala et al. [54] found that ABCG2(+) cells could produce ABCG2(-) cells, and both types of cells have similar tumorigenicity and colony formation ability. 30\% of human cancer cell lines (and more in the bone marrow) and xenografts contain $0.04 \%$ to $0.20 \%$ of SP cells (low but detectable), yet most of the primary tumor cells have only a very small portion of the SP cells, almost impossible to detect $[55,56]$. Giving the evidence that non-recurrent PCa samples presented relatively lower level of ABCG2, compared to both normal tissue and recurrent samples, it might be associated with chemo-sensitivity [57]. Whether ABCG2 could be used as a specific biomarker in PCa diagnosis and prognosis is still unclear and requires further research.

\section{SOX2 and EZH2}

SOX2 and EZH2 are essential for the development of human embryonic stem cells. SOX2 is a transcription factor and plays a key role in maintaining undifferentiated status and keeping self-renewal ability of embryonic stem cells [58]. EZH2 is critical for embryonic stem cells rebuilding and embryonic development. Studies show that they play a key role in prostate cancer stem cells [32]. Recently, SOX2 and EZH2 are also suggested as markers in malignant glioma patients [59]. Ugolkov et al. [32] analyzed expression of CD44, CD133, Oct4, SOX2 and EZH2 in benign prostate tissues, high grade prostatic intraepithelial neoplasia (HGPIN) and PCa tissues, and found that EZH2 and SOX2 were expressed in $<10 \%$ of benign prostate tissue, HGPINs and prostate cancer. In addition, $82 \%(27 / 33)$ of SOX2+ prostate cancer cases were EZH2+ type, and 100\% (33/33) of cases were CD44 $4^{+}$. On the other hand, CD44 was found in $97 \%$ of benign prostate and HGPIN cases, and in $72 \%$ of prostate cancer cases. CD133 was found in only a small portion of PCa tissues $(6 \%, 4 / 67)$. Oct4 expression was found to be closely correlated with benign and HGPIN, but not with PCa. It is believed that CD44 and Oct4 were expressed in most of benign and malignant prostate cells, which is not likely to be representative for a very small proportion of cancer cells (such as cancer stem cells).

\section{CD166}

CD166 is a newly discovered molecular surface marker of prostate cancer stem cells [60]. CD166 belongs to the Ig family of type I transmembrane proteins, which mediate cell-cell interactions, and have been used as prognostic markers for a variety of cancers [1]. CD166 was reported to enrich sphere-forming activity of WT LSC (hi) and Pten null LSC (hi), and enhance the sphere-forming ability of benign primary human prostate cells in vitro and induce the formation of tubule-like structures in vivo [60]. CD166 could be used to identify and isolate human, murine prostate cancer stem cells and hormone refractory prostate cancer [61]. CD166 protein level is upregulated in human PCa, especially in CRPC patients. Although genetic deletion of murine CD166 in the Pten null PCa model does not interfere with sphere formation or block prostate cancer progression and CRPC development, the presence of CD166 on prostate stem/progenitors and castration resistant sub-population of cells suggest that it could be a surface marker of cell stemness. It could be a potential therapeutic target for prostate cancer therapies, as reduced expression of CD166 might be able to interfere or reverse prostate cancer metastasis.

\section{9. cPAcP}

cPAcP is a prostate specific differentiation antigen. In PCa cells, decreased cPAcP expression is associated with androgen-independent cell proliferation and tumorigenicity as seen in advanced hormone-refractory prostate carcinomas [62]. It was demonstrated that HDAC inhibitor treatment could result in increased cPAcP protein level in cPAcP positive cells, increase androgen responsiveness, 
and exhibit higher inhibitory activities on AR/cPAcP-positive PCa cells than on AR/cPAcP-negative $\mathrm{PCa}$ cells. These data indicate that $\mathrm{CPAcP}$ has potential clinical importance serving as a useful biomarker in the identification of PCa patient sub-population suitable for HDAC inhibitor treatment $[63,64]$.

\section{Hepatocyte Growth Factor}

It was found that prostate cancer stem-like cells (CSCs)/cancer initiating cells (CICs) express hepatocyte growth factor (HGF) and that the HGF/c-MET proto-oncogene product (c-MET) signal has a role in the maintenance of prostate CSCs/CICs in an autocrine fashion. Immunohistochemical staining of HGF was compared to biochemical recurrence after radical prostatectomy, and patients with PCa tumors exhibiting HGF positivity of $5 \%$ or more had a significantly shorter biochemical recurrence-free period than that of patients whose tumor HGF positivity was less than $5 \%(p=0.001)$. In multivariate Cox regression, preoperative PSA and HGF positivity had the potential to be independent predictors of biochemical recurrence following prostatectomy [65].

\section{Tumor-Associated Calcium Signal Transducer 2}

Tumor-associated calcium signal transducer 2 (also known as Trop2) is a type I membrane glycoprotein which transduces intracellular calcium signal and acts as a cell surface receptor [66,67]. Trop2 is highly expressed in epithelial related cancers, and its protein level often correlates with poor prognosis [68-73]. Trop2 positive cells could be identified as a subpopulation of prostate basal cells with stem cell characteristics, and it has been used as an effective marker for isolation of basal prostate progenitor cells [74-76]. In prostate cancer, scientists discovered that Trop2 regulate cancer cell proliferation, self-renewal, cell-cell adhesion and metastasis through $\beta$-catenin and $\beta 1$-integrin signaling pathways [77-79]. Interestingly, Trop2 expression in prostate cancer cells was regulated by energy restriction, glucose deprivation and methylation [80-82], making it a potential drug target in cancer treatment. Moreover, anti-Trop2 bispecific antibody was approved to effectively lead pre-targeted immunoPET and radioimmunotherapy of PCa in preclinical models, which significantly increased PCa related survival $[83,84]$.

\section{CD117}

CD117 (also known as c-Kit) is a receptor tyrosine kinase protein, and has been used as an important cell surface marker to identify hematopoietic progenitors in bone marrow [85-87]. CD117 overexpression was observed in several types of solid tumors including prostate $[88,89]$, and is correlated with the capacity of cell self-renewal and cancer progression $[90,91]$. Circulating CD117 positive cell percentage is correlated with cancer progression and PSA values in advanced PCa [92]. CD117 could be activated by its ligand, Stem Cell Factor (SCF), to promote bone marrow cell migration, tumor dissemination and potential bone metastasis [91-94].

\section{AR Splice Variants}

AR splice variants were found to promote EMT as well as induce the expression of stem cell signature genes [95]. Over 10 different AR splice variants were discovered in PCa cell lines, PCa xenografts and human patient samples, and a few of them were dissected to understand their functions in cancer progression [96-103]. More importantly, AR splice variants, such as AR-V7, were suggested to contribute to the drug resistance after suppression of AR signaling, especially in CRPCs [104,105]. High level of AR-V7 was observed in CRPC specimen, but rarely in hormone-naïve specimen [102]. It was suggested that transition from negative to positive status of AR-V7 might reflect the selective pressures on tumor, which makes it a dynamic marker for PCa diagnosis based on liquid biopsy samples, such as circulating tumor cells (CTC) [106]. 


\section{TGM2}

Transglutaminases are enzymes that catalyze the crosslinking of proteins by epsilon- $\gamma$ glutamyl lysine isopeptide bonds. While the primary structure of transglutaminases is not conserved, they all have the same amino acid sequence at their active sites and their activity is calcium-dependent. The protein encoded by this gene acts as a monomer, is induced by retinoic acid, and appears to be involved in apoptosis. TGM2 expression is shown to negatively regulate AR expression and to attenuate androgen sensitivity of prostate cancer cells [107]. TGM2 activation of NF- $\mathrm{kB}$ expression induces NF- $\mathrm{BB}$ binding to DNA elements in the AR gene to reduce AR gene expression, and triggers epithelial-mesenchymal transition [107]. This suggests that TGM2-regulated inflammatory signaling may contribute to the androgen dependence of prostate cancer cells [107]. Thus, TGM2 is concluded as a cancer stem cell survival factor in various types of cancers, including prostate cancer [108].

\section{Conclusions}

Studies of prostate cancer stem cells have gained much progress in the past few years and numerous potential approaches were discussed for novel PCa treatment [109,110]. This review summarizes the major intracellular PCa stem cell biomarkers, including a few novel markers discovered recently. The normal or pathological process and potential drug response reflected by those biomarkers were discussed, which might help with early diagnosis, prevention, drug target identification, drug response evaluation and so on. With the progress in study of circulating biomarkers, we expect that more candidates would be identified to facilitate PCa biopsies, especially those soluble markers (circulating tumor cells (CTCs), circulating tumor nucleic acid (ctNAs), miRNA, IncRNA, exosomes, etc.) for liquid biopsies.

Acknowledgments: This work is supported by NIH grant CA079448 to Xiaolan Fang.

Conflicts of Interest: The authors declare no conflict of interest.

\section{References}

1. Siegel, R.; Ma, J.; Zou, Z.; Jemal, A. Cancer statistics, 2014. CA Cancer J. Clin. 2014, 64, 9-29. [CrossRef] [PubMed]

2. Monsef, N.; Soller, M.; Isaksson, M.; Abrahamsson, P.A.; Panagopoulos, I. The expression of pluripotency marker Oct $3 / 4$ in prostate cancer and benign prostate hyperplasia. Prostate 2009, 69, 909-916. [CrossRef] [PubMed]

3. Attard, G.; Parker, C.; Eeles, R.A.; Schroder, F.; Tomlins, S.A.; Tannock, I.; Drake, C.G.; de Bono, J.S. Prostate Cancer. Lancet 2016, 387, 70-82. [CrossRef]

4. Zong, Y.; Goldstein, A.S. Adaptation or selection-Mechanisms of castration-resistant prostate cancer. Nat. Rev. Urol. 2013, 10, 90-98. [CrossRef] [PubMed]

5. Isaacs, J.T.; Coffey, D.S. Adaptation versus selection as the mechanism responsible for the relapse of prostatic cancer to androgen ablation therapy as studied in the Dunning R-3327-H adenocarcinoma. Cancer Res. 1981, 41, 5070-5075. [PubMed]

6. Blum, R.; Gupta, R.; Burger, P.E.; Ontiveros, C.S.; Salm, S.N.; Xiong, X.; Kamb, A.; Wesche, H.; Marshall, L.; Cutler, G.; et al. Molecular signatures of prostate stem cells reveal novel signaling pathways and provide insights into prostate cancer. PLoS ONE 2009, 4, e5722. [CrossRef] [PubMed]

7. Lang, S.H.; Frame, F.M.; Collins, A.T. Prostate cancer stem cells. J. Pathol. 2009, 217, 299-306. [CrossRef] [PubMed]

8. Chen, X.; Rycaj, K.; Liu, X.; Tang, D.G. New insights into prostate cancer stem cells. Cell Cycle 2013, 12, 579-586. [CrossRef] [PubMed]

9. Rane, J.K.; Pellacani, D.; Maitland, N.J. Advanced prostate cancer-A case for adjuvant differentiation therapy. Nat. Rev. Urol. 2012, 9, 595-602. [CrossRef] [PubMed]

10. Castillo, V.; Valenzuela, R.; Huidobro, C.; Contreras, H.R.; Castellon, E.A. Functional characteristics of cancer stem cells and their role in drug resistance of prostate cancer. Int. J. Oncol. 2014, 45, 985-994. [CrossRef] [PubMed] 
11. McMillen, P.; Holley, S.A. Integration of cell-cell and cell-ECM adhesion in vertebrate morphogenesis. Curr. Opin. Cell Biol. 2015, 36, 48-53. [CrossRef] [PubMed]

12. Van Slambrouck, S.; Groux-Degroote, S.; Krzewinski-Recchi, M.A.; Cazet, A.; Delannoy, P.; Steelant, W.F. Carbohydrate-to-carbohydrate interactions between $\alpha 2,3$-linked sialic acids on $\alpha 2$ integrin subunits and asialo-GM1 underlie the bone metastatic behaviour of LNCAP-derivative C4-2B prostate cancer cells. Biosci. Rep. 2014, 34. [CrossRef] [PubMed]

13. Dedhar, S.; Saulnier, R.; Nagle, R.; Overall, C.M. Specific alterations in the expression of $\alpha 3 \beta 1$ and $\alpha 6 \beta 4$ integrins in highly invasive and metastatic variants of human prostate carcinoma cells selected by in vitro invasion through reconstituted basement membrane. Clin. Exp. Metastasis 1993, 11, 391-400. [CrossRef] [PubMed]

14. Hoogland, A.M.; Verhoef, E.I.; Roobol, M.J.; Schroder, F.H.; Wildhagen, M.F.; van der Kwast, T.H.; Jenster, G.; van Leenders, G.J. Validation of stem cell markers in clinical prostate cancer: $\alpha$ 6-integrin is predictive for non-aggressive disease. Prostate 2014, 74, 488-496. [CrossRef] [PubMed]

15. Collins, A.T.; Habib, F.K.; Maitland, N.J.; Neal, D.E. Identification and isolation of human prostate epithelial stem cells based on $\alpha_{2} \beta_{1}$-integrin expression. J. Cell Sci. 2001, 114, 3865-3872. [PubMed]

16. Fortunel, N.O.; Otu, H.H.; Ng, H.-H.; Chen, J.; Mu, X.; Chevassut, T.; Li, X.; Joseph, M.; Bailey, C.; Hatzfeld, J.A.; et al. Comment on "Stemness': Transcriptional Profiling of Embryonic and Adult Stem Cells" and "A Stem Cell Molecular Signature" (I). Science 2003, 302, 393. [CrossRef] [PubMed]

17. Barclay, W.W.; Axanova, L.S.; Chen, W.; Romero, L.; Maund, S.L.; Soker, S.; Lees, C.J.; Cramer, S.D. Characterization of Adult Prostatic Progenitor/Stem Cells Exhibiting Self-Renewal and Multilineage Differentiation. Stem Cells 2008, 26, 600-610. [CrossRef] [PubMed]

18. Lawson, D.A.; Xin, L.; Lukacs, R.U.; Cheng, D.; Witte, O.N. Isolation and functional characterization of murine prostate stem cells. Proc. Natl. Acad. Sci. USA 2007, 104, 181-186. [CrossRef] [PubMed]

19. Marthick, J.R.; Dickinson, J.L. Emerging Putative Biomarkers: The Role of $\alpha 2$ and 6 Integrins in Susceptibility, Treatment, and Prognosis. Prostate Cancer 2012, 2012, 298732. [CrossRef] [PubMed]

20. Finetti, F.; Terzuoli, E.; Giachetti, A.; Santi, R.; Villari, D.; Hanaka, H.; Radmark, O.; Ziche, M.; Donnini, S. mPGES-1 in prostate cancer controls stemness and amplifies epidermal growth factor receptor-driven oncogenicity. Endocr. Relat. Cancer 2015, 22, 665-678. [CrossRef] [PubMed]

21. Lokeshwar, B.L.; Lokeshwar, V.B.; Block, N.L. Expression of CD44 in prostate cancer cells: Association with cell proliferation and invasive potential. Anticancer Res. 1995, 15, 1191-1198. [PubMed]

22. Liu, A.Y. Expression of CD44 in prostate cancer cells. Cancer Lett. 1994, 76, 63-69. [CrossRef]

23. Collins, A.T.; Berry, P.A.; Hyde, C.; Stower, M.J.; Maitland, N.J. Prospective identification of tumorigenic prostate cancer stem cells. Cancer Res. 2005, 65, 10946-10951. [CrossRef] [PubMed]

24. Ajani, J.A.; Song, S.; Hochster, H.S.; Steinberg, I.B. Cancer stem cells: The promise and the potential. Semin. Oncol. 2015, 42 (Suppl. S1), S3-S17. [CrossRef] [PubMed]

25. Wang, L.; Huang, X.; Zheng, X.; Wang, X.; Li, S.; Zhang, L.; Yang, Z.; Xia, Z. Enrichment of prostate cancer stem-like cells from human prostate cancer cell lines by culture in serum-free medium and chemoradiotherapy. Int. J. Biol. Sci. 2013, 9, 472-479. [CrossRef] [PubMed]

26. Yu, J.; Lu, Y.; Cui, D.; Li, E.; Zhu, Y.; Zhao, Y.; Zhao, F.; Xia, S. miR-200b suppresses cell proliferation, migration and enhances chemosensitivity in prostate cancer by regulating Bmi-1. Oncol. Rep. 2014, 31, 910-918. [PubMed]

27. Ibuki, N.; Ghaffari, M.; Pandey, M.; Iu, I.; Fazli, L.; Kashiwagi, M.; Tojo, H.; Nakanishi, O.; Gleave, M.E.; Cox, M.E. TAK-441, a novel investigational smoothened antagonist, delays castration-resistant progression in prostate cancer by disrupting paracrine hedgehog signaling. Int. J. Cancer. 2013, 133, 1955-1966. [CrossRef] [PubMed]

28. Kasper, S. Identification, characterization, and biological relevance of prostate cancer stem cells from clinical specimens. Urol. Oncol. 2009, 27, 301-303. [CrossRef] [PubMed]

29. Van Leenders, G.J.; Schalken, J.A. Stem cell differentiation within the human prostate epithelium: Implications for prostate carcinogenesis. BJU Int. 2001, 88 (Suppl. S2), 35-42. [CrossRef] [PubMed]

30. Korski, K.; Malicka-Durczak, A.; Breborowicz, J. Expression of stem cell marker CD44 in prostate cancer biopsies predicts cancer grade in radical prostatectomy specimens. Pol. J. Pathol. 2014, 65, 291-295. [CrossRef] [PubMed] 
31. Liu, C.; Kelnar, K.; Liu, B.; Chen, X.; Calhoun-Davis, T.; Li, H.; Patrawala, L.; Yan, H.; Jeter, C.; Honorio, S.; et al. The microRNA miR-34a inhibits prostate cancer stem cells and metastasis by directly repressing CD44. Nat. Med. 2011, 17, 211-215. [CrossRef] [PubMed]

32. Ugolkov, A.V.; Eisengart, L.J.; Luan, C.; Yang, X.J. Expression analysis of putative stem cell markers in human benign and malignant prostate. Prostate 2011, 71, 18-25. [CrossRef] [PubMed]

33. Moura, C.M.; Pontes, J.; Reis, S.T.; Viana, N.I.; Morais, D.R.; Dip, N.; Katz, B.; Srougi, M.; Leite, K.R.M. Expression profile of standard and variants forms of CD44 related to prostate cancer behavior. Int. J. Biol. Markers 2015, 30, e49-e55. [CrossRef] [PubMed]

34. Tei, H.; Miyake, H.; Harada, K.-I.; Fujisawa, M. Expression profile of CD44s, CD44v6, and CD44v10 in localized prostate cancer: Effect on prognostic outcomes following radical prostatectomy. Urol. Oncol. Semin. Orig. Investig. 2014, 32, 694-700. [CrossRef] [PubMed]

35. Ni, J.; Cozzi, P.J.; Hao, J.L.; Beretov, J.; Chang, L.; Duan, W.; Shigdar, S.; Delprado, W.J.; Graham, P.H.; Bucci, J.; et al. CD44 variant 6 is associated with prostate cancer metastasis and chemo-/radioresistance. Prostate 2014, 74, 602-617. [CrossRef] [PubMed]

36. Yang, K.; Tang, Y.; Habermehl, G.K.; Iczkowski, K.A. Stable alterations of CD44 isoform expression in prostate cancer cells decrease invasion and growth and alter ligand binding and chemosensitivity. BMC Cancer 2010, 10, 16. [CrossRef] [PubMed]

37. Choy, W.; Nagasawa, D.T.; Trang, A.; Thill, K.; Spasic, M.; Yang, I. CD133 as a marker for regulation and potential for targeted therapies in glioblastoma multiforme. Neurosurg. Clin. N. Am. 2012, 23, 391-405. [CrossRef] [PubMed]

38. Islam, F.; Gopalan, V.; Wahab, R.; Smith, R.A.; Lam, A.K. Cancer stem cells in oesophageal squamous cell carcinoma: Identification, prognostic and treatment perspectives. Crit. Rev. Oncol./Hematol. 2015, 96, 9-19. [CrossRef] [PubMed]

39. Zhou, Q.; Chen, A.; Song, H.; Tao, J.; Yang, H.; Zuo, M. Prognostic value of cancer stem cell marker CD133 in ovarian cancer: A meta-analysis. Int. J. Clin. Exp. Med. 2015, 8, 3080-3088. [PubMed]

40. Han, G.W.; Yi, S.H. Prostate stem cells: An update. Zhonghua Nan Ke Xue 2014, 20, 460-463. [PubMed]

41. Zenzmaier, C.; Untergasser, G.; Berger, P. Aging of the prostate epithelial stem/progenitor cell. Exp. Gerontol. 2008, 43, 981-985. [CrossRef] [PubMed]

42. Missol-Kolka, E.; Karbanova, J.; Janich, P.; Haase, M.; Fargeas, C.A.; Huttner, W.B.; Corbeil, D. Prominin-1 (CD133) is not restricted to stem cells located in the basal compartment of murine and human prostate. Prostate 2011, 71, 254-267. [CrossRef] [PubMed]

43. Hsu, W.T.; Jui, H.Y.; Huang, Y.H.; Su, M.Y.; Wu, Y.W.; Tseng, W.Y.; Hsu, M.C.; Chiang, B.L.; Wu, K.K.; Lee, C.M. CXCR4 Antagonist TG-0054 Mobilizes Mesenchymal Stem Cells, Attenuates Inflammation, and Preserves Cardiac Systolic Function in a Porcine Model of Myocardial Infarction. Cell Transplant. 2015, 24, 1313-1328. [CrossRef] [PubMed]

44. Trerotola, M.; Rathore, S.; Goel, H.L.; Li, J.; Alberti, S.; Piantelli, M.; Adams, D.; Jiang, Z.; Languino, L.R. CD133, Trop-2 and $\alpha 2 \beta 1$ integrin surface receptors as markers of putative human prostate cancer stem cells. Am. J. Transl. Res. 2010, 2, 135-144. [PubMed]

45. Taylor, R.A.; Toivanen, R.; Frydenberg, M.; Pedersen, J.; Harewood, L.; Australian Prostate Cancer Bioresource; Collins, A.T.; Maitland, N.J.; Risbridger, G.P. Human epithelial basal cells are cells of origin of prostate cancer, independent of CD133 status. Stem Cells 2012, 30, 1087-1096. [CrossRef] [PubMed]

46. Liu, J.F.; Xia, P.; Hu, W.Q.; Wang, D.; Xu, X.Y. Aldehyde dehydrogenase 1 expression correlates with clinicopathologic features of patients with breast cancer: A meta-analysis. Int. J. Clinl. Exp. Med. 2015, 8, 8425-8432.

47. Schnier, J.B.; Kaur, G.; Kaiser, A.; Stinson, S.F.; Sausville, E.A.; Gardner, J.; Nishi, K.; Bradbury, E.M.; Senderowicz, A.M. Identification of cytosolic aldehyde dehydrogenase 1 from non-small cell lung carcinomas as a flavopiridol-binding protein. FEBS Lett. 1999, 454, 100-104. [CrossRef]

48. Li, T.; Su, Y.; Mei, Y.; Leng, Q.; Leng, B.; Liu, Z.; Stass, S.A.; Jiang, F. ALDH1A1 is a marker for malignant prostate stem cells and predictor of prostate cancer patients' outcome. Lab. Investig. J. Tech. Methods Pathol. 2010, 90, 234-244. [CrossRef] [PubMed]

49. Burger, P.E.; Gupta, R.; Xiong, X.; Ontiveros, C.S.; Salm, S.N.; Moscatelli, D.; Wilson, E.L. High aldehyde dehydrogenase activity: A novel functional marker of murine prostate stem/progenitor cells. Stem Cells 2009, 27, 2220-2228. [CrossRef] [PubMed] 
50. Wang, G.; Wang, Z.; Sarkar, F.H.; Wei, W. Targeting prostate cancer stem cells for cancer therapy. Discov. Med. 2012, 13, 135-142. [PubMed]

51. Gangavarapu, K.J.; Azabdaftari, G.; Morrison, C.D.; Miller, A.; Foster, B.A.; Huss, W.J. Aldehyde dehydrogenase and ATP binding cassette transporter G2 (ABCG2) functional assays isolate different populations of prostate stem cells where ABCG2 function selects for cells with increased stem cell activity. Stem Cell Res. Ther. 2013, 4, 132. [CrossRef] [PubMed]

52. Ferronika, P.; Triningsih, F.X.; Ghozali, A.; Moeljono, A.; Rahmayanti, S.; Shadrina, A.N.; Naim, A.E.; Wudexi, I.; Arnurisa, A.M.; Nanwani, S.T.; et al. p63 cytoplasmic aberrance is associated with high prostate cancer stem cell expression. Asian Pac. J. Cancer Prev. (APJCP) 2012, 13, 1943-1948. [CrossRef] [PubMed]

53. An, Y.; Ongkeko, W.M. ABCG2: The key to chemoresistance in cancer stem cells? Expert Opin. Drug Metab. Toxicol. 2009, 5, 1529-1542. [CrossRef] [PubMed]

54. Patrawala, L.; Calhoun, T.; Schneider-Broussard, R.; Zhou, J.; Claypool, K.; Tang, D.G. Side population is enriched in tumorigenic, stem-like cancer cells, whereas ABCG2 ${ }^{+}$and ABCG2- cancer cells are similarly tumorigenic. Cancer Res. 2005, 65, 6207-6219. [CrossRef] [PubMed]

55. Kim, H.A.; Kim, M.C.; Kim, N.Y.; Kim, Y. Inhibition of hedgehog signaling reduces the side population in human malignant mesothelioma cell lines. Cancer Gene Ther. 2015, 22, 387-395. [CrossRef] [PubMed]

56. Gao, G.; Sun, Z.; Wenyong, L.; Dongxia, Y.; Zhao, R.; Zhang, X. A preliminary study of side population cells in human gastric cancer cell line HGC-27. Ann. Transplant. Q. Pol. Transplant. Soc. 2015, 20, 147-153.

57. Guzel, E.; Karatas, O.F.; Duz, M.B.; Solak, M.; Ittmann, M.; Ozen, M. Differential expression of stem cell markers and ABCG2 in recurrent prostate cancer. Prostate 2014, 74, 1498-1505. [CrossRef] [PubMed]

58. Fu, T.Y.; Hsieh, I.C.; Cheng, J.T.; Tsai, M.H.; Hou, Y.Y.; Lee, J.H.; Liou, H.H.; Huang, S.F.; Chen, H.C.; Yen, L.M.; et al. Association of OCT4, SOX2, and NANOG expression with oral squamous cell carcinoma progression. J. Oral Pathol. Med. 2015, 45, 89-95. [CrossRef] [PubMed]

59. Li, A.M.; Dunham, C.; Tabori, U.; Carret, A.S.; McNeely, P.D.; Johnston, D.; Lafay-Cousin, L.; Wilson, B.; Eisenstat, D.D.; Jabado, N.; et al. EZH2 expression is a prognostic factor in childhood intracranial ependymoma: A Canadian Pediatric Brain Tumor Consortium study. Cancer 2015, 121, 1499-1507. [CrossRef] [PubMed]

60. Jiao, J.; Hindoyan, A.; Wang, S.; Tran, L.M.; Goldstein, A.S.; Lawson, D.; Chen, D.; Li, Y.; Guo, C.; Zhang, B.; et al. Identification of CD166 as a surface marker for enriching prostate stem/progenitor and cancer initiating cells. PLoS ONE 2012, 7, e42564. [CrossRef] [PubMed]

61. Rowehl, R.A.; Crawford, H.; Dufour, A.; Ju, J.; Botchkina, G.I. Genomic analysis of prostate cancer stem cells isolated from a highly metastatic cell line. Cancer Genom. Proteom. 2008, 5, 301-310.

62. Chuang, T.-D.; Chen, S.-J.; Lin, F.-F.; Veeramani, S.; Kumar, S.; Batra, S.K.; Tu, Y.; Lin, M.-F. Human Prostatic Acid Phosphatase, an Authentic Tyrosine Phosphatase, Dephosphorylates ErbB-2 and Regulates Prostate Cancer Cell Growth. J. Biol. Chem. 2010, 285, 23598-23606. [CrossRef] [PubMed]

63. Chou, Y.W.; Lin, F.F.; Muniyan, S.; Lin, F.C.; Chen, C.S.; Wang, J.; Huang, C.C.; Lin, M.F. Cellular prostatic acid phosphatase (cPAcP) serves as a useful biomarker of histone deacetylase (HDAC) inhibitors in prostate cancer cell growth suppression. Cell Biosci. 2015, 5, 38. [CrossRef] [PubMed]

64. Chou, Y.W.; Chaturvedi, N.K.; Ouyang, S.; Lin, F.F.; Kaushik, D.; Wang, J.; Kim, I.; Lin, M.F. Histone deacetylase inhibitor valproic acid suppresses the growth and increases the androgen responsiveness of prostate cancer cells. Cancer Lett. 2011, 311, 177-186. [CrossRef] [PubMed]

65. Nishida, S.; Hirohashi, Y.; Torigoe, T.; Nojima, M.; Inoue, R.; Kitamura, H.; Tanaka, T.; Asanuma, H.; Sato, N.; Masumori, N. Expression of hepatocyte growth factor in prostate cancer may indicate a biochemical recurrence after radical prostatectomy. Anticancer Res. 2015, 35, 413-418. [CrossRef]

66. Fornaro, M.; Dell'Arciprete, R.; Stella, M.; Bucci, C.; Nutini, M.; Capri, M.G.; Alberti, S. Cloning of the gene encoding Trop-2, a cell-surface glycoprotein expressed by human carcinomas. Int. J. Cancer 1995, 62, 610-618. [CrossRef] [PubMed]

67. Ripani, E.; Sacchetti, A.; Corda, D.; Alberti, S. Human Trop-2 is a tumor-associated calcium signal transducer. Int. J. Cancer 1998, 76, 671-676. [CrossRef]

68. Mühlmann, G.; Spizzo, G.; Gostner, J.; Zitt, M.; Maier, H.; Moser, P.; Gastl, G.; Müller, H.M.; Margreiter, R.; Öfner, D.; et al. TROP2 expression as prognostic marker for gastric carcinoma. J. Clin. Pathol. 2009, 62, 152-158. [CrossRef] [PubMed] 
69. Fang, Y.J.; Lu, Z.H.; Wang, G.Q.; Pan, Z.Z.; Zhou, Z.W.; Yun, J.P.; Zhang, M.F.; Wan, D.S. Elevated expressions of MMP7, TROP2, and survivin are associated with survival, disease recurrence, and liver metastasis of colon cancer. Int. J. Colorectal. Dis. 2009, 24, 875-884. [CrossRef] [PubMed]

70. Nakashima, K.; Shimada, H.; Ochiai, T.; Kuboshima, M.; Kuroiwa, N.; Okazumi, S.; Matsubara, H.; Nomura, F.; Takiguchi, M.; Hiwasa, T. Serological identification of TROP2 by recombinant cDNA expression cloning using sera of patients with esophageal squamous cell carcinoma. Int. J. Cancer 2004, 112, 1029-1035. [CrossRef] [PubMed]

71. Ohmachi, T.; Tanaka, F.; Mimori, K.; Inoue, H.; Yanaga, K.; Mori, M. Clinical Significance of TROP2 Expression in Colorectal Cancer. Clin. Cancer Res. 2006, 12, 3057-3063. [CrossRef] [PubMed]

72. Fong, D.; Moser, P.; Krammel, C.; Gostner, J.M.; Margreiter, R.; Mitterer, M.; Gastl, G.; Spizzo, G. High expression of TROP2 correlates with poor prognosis in pancreatic cancer. Br. J. Cancer 2008, 99, 1290-1295. [CrossRef] [PubMed]

73. Köbel, M.; Kalloger, S.E.; Boyd, N.; McKinney, S.; Mehl, E.; Palmer, C.; Leung, S.; Bowen, N.J.; Ionescu, D.N.; Rajput, A.; et al. Ovarian carcinoma subtypes are different diseases: Implications for biomarker studies. PLoS Med. 2008, 5, e232. [CrossRef] [PubMed]

74. Höfner, T.; Eisen, C.; Klein, C.; Rigo-Watermeier, T.; Goeppinger, S.M.; Jauch, A.; Schoell, B.; Vogel, V.; Noll, E.; Weichert, W.; et al. Defined Conditions for the Isolation and Expansion of Basal Prostate Progenitor Cells of Mouse and Human Origin. Stem Cell Rep. 2015, 4, 503-518. [CrossRef] [PubMed]

75. Goldstein, A.S.; Lawson, D.A.; Cheng, D.; Sun, W.; Garraway, I.P.; Witte, O.N. Trop2 identifies a subpopulation of murine and human prostate basal cells with stem cell characteristics. Proc. Natl. Acad. Sci. USA 2008, 105, 20882-20887. [CrossRef] [PubMed]

76. Fedr, R.; Pernicová, Z.; Slabáková, E.; Straková, N.; Bouchal, J.; Grepl, M.; Kozubík, A.; Souček, K. Automatic cell cloning assay for determining the clonogenic capacity of cancer and cancer stem-like cells. Cytom. A 2013, 83, 472-482. [CrossRef] [PubMed]

77. Stoyanova, T.; Goldstein, A.S.; Cai, H.; Drake, J.M.; Huang, J.; Witte, O.N. Regulated proteolysis of Trop2 drives epithelial hyperplasia and stem cell self-renewal via $\beta$-catenin signaling. Genes Dev. 2012, 26, 2271-2285. [CrossRef] [PubMed]

78. Trerotola, M.; Jernigan, D.L.; Liu, Q.; Siddiqui, J.; Fatatis, A.; Languino, L.R. Trop-2 promotes prostate cancer metastasis by modulating $\beta_{1}$ integrin functions. Cancer Res. 2013, 73, 3155-3167. [CrossRef] [PubMed]

79. Trerotola, M.; Li, J.; Alberti, S.; Languino, L.R. Trop-2 inhibits prostate cancer cell adhesion to fibronectin through the $\beta 1$ integrin-RACK1 axis. J. Cell. Physiol. 2012, 227, 3670-3677. [CrossRef] [PubMed]

80. Ibragimova, I.; de Cáceres, I.I.; Hoffman, A.M.; Potapova, A.; Dulaimi, E.; Al-Saleem, T.; Hudes, G.R.; Ochs, M.F.; Cairns, P. Global Reactivation of Epigenetically Silenced Genes in Prostate Cancer. Cancer Prev. Res. 2010, 3, 1084-1092. [CrossRef] [PubMed]

81. Jerónimo, C.; Esteller, M. DNA Methylation Markers for Prostate Cancer with a Stem Cell Twist. Cancer Prev. Res. 2010, 3, 1053-1055. [CrossRef] [PubMed]

82. Lin, H.-Y.; Kuo, Y.-C.; Weng, Y.-I.; Lai, I.L.; Huang, T.H.M.; Lin, S.-P.; Niu, D.-M.; Chen, C.-S. Activation of Silenced Tumor Suppressor Genes in Prostate Cancer Cells by a Novel Energy Restriction-Mimetic Agent. Prostate 2012, 72. [CrossRef] [PubMed]

83. Van Rij, C.M.; Frielink, C.; Goldenberg, D.M.; Sharkey, R.M.; Lutje, S.; McBride, W.J.; Oyen, W.J.; Boerman, O.C. Pretargeted Radioimmunotherapy of Prostate Cancer with an Anti-TROP-2× Anti-HSG Bispecific Antibody and a ${ }^{177}$ Lu-Labeled Peptide. Cancer Biother. Radiopharm. 2014, 29, 323-329. [CrossRef] [PubMed]

84. Van Rij, C.M.; Lutje, S.; Frielink, C.; Sharkey, R.M.; Goldenberg, D.M.; Franssen, G.M.; McBride, W.J.; Rossi, E.A.; Oyen, W.J.; Boerman, O.C. Pretargeted immuno-PET and radioimmunotherapy of prostate cancer with an anti-TROP-2× anti-HSG bispecific antibody. Eur. J. Nucl. Med. Mol. Imaging 2013, 40, 1377-1383. [CrossRef] [PubMed]

85. Yarden, Y.; Kuang, W.J.; Yang-Feng, T.; Coussens, L.; Munemitsu, S.; Dull, T.J.; Chen, E.; Schlessinger, J.; Francke, U.; Ullrich, A. Human proto-oncogene c-kit: A new cell surface receptor tyrosine kinase for an unidentified ligand. EMBO J. 1987, 6, 3341-3351. [PubMed]

86. Matthews, W.; Jordan, C.T.; Wiegand, G.W.; Pardoll, D.; Lemischka, I.R. A receptor tyrosine kinase specific to hematopoietic stem and progenitor cell-enriched populations. Cell 1991, 65, 1143-1152. [CrossRef] 
87. Broxmeyer, H.E.; Maze, R.; Miyazawa, K.; Carow, C.; Hendrie, P.C.; Cooper, S.; Hangoc, G.; Vadhan-Raj, S.; $\mathrm{Lu}, \mathrm{L}$. The kit receptor and its ligand, steel factor, as regulators of hemopoiesis. Cancer Cells 1991, 3, 480-487. [PubMed]

88. Chi, P.; Chen, Y.; Zhang, L.; Guo, X.; Wongvipat, J.; Shamu, T.; Fletcher, J.A.; Dewell, S.; Maki, R.G.; Zheng, D.; et al. ETV1 is a lineage-specific survival factor in GIST and cooperates with KIT in oncogenesis. Nature 2010, 467, 849-853. [CrossRef] [PubMed]

89. Di Lorenzo, G.; Autorino, R.; D’Armiento, F.P.; Mignogna, C.; de Laurentiis, M.; de Sio, M.; D'Armiento, M.; Damiano, R.; Vecchio, G.; de Placido, S. Expression of proto-oncogene c-kit in high risk prostate cancer. Eur. J. Surg. Oncol. 2004, 30, 987-992. [CrossRef] [PubMed]

90. Leong, K.G.; Wang, B.E.; Johnson, L.; Gao, W.Q. Generation of a prostate from a single adult stem cell. Nature 2008, 456, 804-808. [CrossRef] [PubMed]

91. Wiesner, C.; Nabha, S.M.; Dos Santos, E.B.; Yamamoto, H.; Meng, H.; Melchior, S.W.; Bittinger, F.; Thüroff, J.W.; Vessella, R.L.; Cher, M.L.; et al. C-Kit and Its Ligand Stem Cell Factor: Potential Contribution to Prostate Cancer Bone Metastasis. Neoplasia 2008, 10, 996-1003. [CrossRef] [PubMed]

92. Kerr, B.A.; Miocinovic, R.; Smith, A.K.; West, X.Z.; Watts, K.E.; Alzayed, A.W.; Klink, J.C.; Mir, M.C.; Sturey, T.; Hansel, D.E.; et al. CD117 ${ }^{+}$cells in the circulation are predictive of advanced prostate cancer. Oncotarget 2015, 6, 1889-1897. [CrossRef] [PubMed]

93. Okumura, N.; Tsuji, K.; Ebihara, Y.; Tanaka, I.; Sawai, N.; Koike, K.; Komiyama, A.; Nakahata, T. Chemotactic and chemokinetic activities of stem cell factor on murine hematopoietic progenitor cells. Blood 1996, 87, 4100-4108. [PubMed]

94. Blume-Jensen, P.; Claesson-Welsh, L.; Siegbahn, A.; Zsebo, K.M.; Westermark, B.; Heldin, C.H. Activation of the human c-kit product by ligand-induced dimerization mediates circular actin reorganization and chemotaxis. EMBO J. 1991, 10, 4121-4128. [PubMed]

95. Kong, D.; Sethi, S.; Li, Y.; Chen, W.; Sakr, W.A.; Heath, E.; Sarkar, F.H. Androgen receptor splice variants contribute to prostate cancer aggressiveness through induction of EMT and expression of stem cell marker genes. Prostate 2015, 75, 161-174. [CrossRef] [PubMed]

96. Guo, Z.; Yang, X.; Sun, F.; Jiang, R.; Linn, D.E.; Chen, H.; Chen, H.; Kong, X.; Melamed, J.; Tepper, C.G.; et al. A novel androgen receptor splice variant is up-regulated during prostate cancer progression and promotes androgen depletion-resistant growth. Cancer Res. 2009, 69, 2305-2313. [CrossRef] [PubMed]

97. Marcias, G.; Erdmann, E.; Lapouge, G.; Siebert, C.; Barthélémy, P.; Duclos, B.; Bergerat, J.-P.; Céraline, J.; Kurtz, J.-E. Identification of novel truncated androgen receptor (AR) mutants including unreported pre-mRNA splicing variants in the 22Rv1 hormone-refractory prostate cancer (PCa) cell line. Hum. Mutat. 2010, 31, 74-80. [CrossRef] [PubMed]

98. Sun, S.; Sprenger, C.C.T.; Vessella, R.L.; Haugk, K.; Soriano, K.; Mostaghel, E.A.; Page, S.T.; Coleman, I.M.; Nguyen, H.M.; Sun, H.; et al. Castration resistance in human prostate cancer is conferred by a frequently occurring androgen receptor splice variant. J. Clin. Investig. 2010, 120, 2715-2730. [CrossRef] [PubMed]

99. Hu, R.; Isaacs, W.B.; Luo, J. A snapshot of the expression signature of androgen receptor splicing variants and their distinctive transcriptional activities. Prostate 2011, 71, 1656-1667. [CrossRef] [PubMed]

100. Watson, P.A.; Chen, Y.F.; Balbas, M.D.; Wongvipat, J.; Socci, N.D.; Viale, A.; Kim, K.; Sawyers, C.L. Constitutively active androgen receptor splice variants expressed in castration-resistant prostate cancer require full-length androgen receptor. Proc. Natl. Acad. Sci. USA 2010, 107, 16759-16765. [CrossRef] [PubMed]

101. Dehm, S.M.; Schmidt, L.J.; Heemers, H.V.; Vessella, R.L.; Tindall, D.J. Splicing of a Novel Androgen Receptor Exon Generates a Constitutively Active Androgen Receptor that Mediates Prostate Cancer Therapy Resistance. Cancer Res. 2008, 68, 5469-5477. [CrossRef] [PubMed]

102. Hu, R.; Dunn, T.A.; Wei, S.; Isharwal, S.; Veltri, R.W.; Humphreys, E.; Han, M.; Partin, A.W.; Vessella, R.L.; Isaacs, W.B.; et al. Ligand-Independent Androgen Receptor Variants Derived from Splicing of Cryptic Exons Signify Hormone-Refractory Prostate Cancer. Cancer Res. 2009, 69, 16-22. [CrossRef] [PubMed]

103. Dehm, S.M.; Tindall, D.J. Alternatively spliced androgen receptor variants. Endocr. Relat. Cancer 2011, 18, R183-R196. [CrossRef] [PubMed]

104. Nakazawa, M.; Antonarakis, E.; Luo, J. Androgen Receptor Splice Variants in the Era of Enzalutamide and Abiraterone. Horm. Cancer 2014, 5, 265-273. [CrossRef] [PubMed] 
105. Onstenk, W.; Sieuwerts, A.M.; Kraan, J.; van, M.; Nieuweboer, A.J.M.; Mathijssen, R.H.J.; Hamberg, P.; Meulenbeld, H.J.; de Laere, B.; Dirix, L.Y.; et al. Efficacy of cabazitaxel in castration-resistant prostate cancer is independent of the presence of AR-V7 in circulating tumor cells. Eur. Urol. 2015, 68, 939-945. [CrossRef] [PubMed]

106. Nakazawa, M.; Lu, C.; Chen, Y.; Paller, C.J.; Carducci, M.A.; Eisenberger, M.A.; Luo, J.; Antonarakis, E.S. Serial blood-based analysis of AR-V7 in men with advanced prostate cancer. Ann. Oncol. 2015. [CrossRef] [PubMed]

107. Han, A.L.; Kumar, S.; Fok, J.Y.; Tyagi, A.K.; Mehta, K. Tissue transglutaminase expression promotes castration-resistant phenotype and transcriptional repression of androgen receptor. Eur. J. Cancer 2014, 50, 1685-1696. [CrossRef] [PubMed]

108. Eckert, R.L.; Fisher, M.L.; Grun, D.; Adhikary, G.; Xu, W.; Kerr, C. Transglutaminase is a tumor cell and cancer stem cell survival factor. Mol. Carcinog. 2015, 54, 947-958. [CrossRef] [PubMed]

109. Mayer, M.J.; Klotz, L.H.; Venkateswaran, V. Metformin and prostate cancer stem cells: A novel therapeutic target. Prostate Cancer Prostatic Dis. 2015, 18, 303-309. [CrossRef] [PubMed]

110. Yu, V.Y.; Nguyen, D.; Pajonk, F.; Kupelian, P.; Kaprealian, T.; Selch, M.; Low, D.A.; Sheng, K. Incorporating cancer stem cells in radiation therapy treatment response modeling and the implication in glioblastoma multiforme treatment resistance. Int. J. Radiat. Oncol. Biol. Phys. 2015, 91, 866-875. [CrossRef] [PubMed]

(C) 2016 by the authors; licensee MDPI, Basel, Switzerland. This article is an open access article distributed under the terms and conditions of the Creative Commons Attribution (CC-BY) license (http:/ / creativecommons.org/licenses/by/4.0/). 